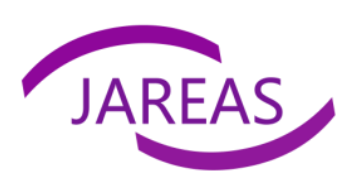

\title{
Working Capital Management and Its Impact on Profitability in Tyre Industry: A Study of Selected Companies
}

\author{
Ajmera Tushar Rameshbhai \\ ${ }^{1}$ Ph.D Research Scholar, Department of Commerce, \\ Saurashtra University, Near Munjka, Rajkot Gujarat-360005, India
}

\begin{tabular}{l} 
Article Info \\
\hline Article history: \\
Received: 22 November 2020 \\
Revised: 18 January 2021 \\
Accepted: 22 January 2021 \\
\hline Keywords: \\
Current Ratio, Quick Ratio, \\
Inventory Turnover Ratio, \\
Working Capital Turnover \\
Ratio, Gross Working Capital, \\
Net Working Capital, \\
Investment Credit Rating \\
Agency. \\
JEL: G30, G31, G32 \\
Paper Type : \\
Research Article \\
\hline Corresponding Author: \\
Ajmera Tushar Rameshbhai \\
Email: \\
ajmera.tushar94@gmail.com
\end{tabular}

\begin{abstract}
Purpose: The main aim of this article is to find out the working capital management and its impact on profitability in Tyre Industry of selected companies which are listed on stock exchange in India.

Approach/Methodology/ Design: For the study, a time span of 8 years from 2011-12 to 2018-19 is considered, and based on it, any relation of net profit margin ratio and working capital components like current ratio, quick ratio, inventory turnover ratio, working capital turnover ratio is considered. The sample is selected based on higher market capitalisation during the study period. Regression analysis is also employed to investigate the impact of WCM on corporate profitability.

Findings: The major findings of this study indicate that the profitability of Balkrishana was good compared to the other companies. The working capital of Ceat shows highly positive working capital management, whereas Apollo shows negative working capital management. These results were identified with the help of accounting tool as Ratio analysis and statistical tools as Regression analysis and ANOVA test for selected data.

Practical Implication: The study examines the scenario of tyre industry with the help of working capital management in selected companies. The results of the study could be an indicator of the performance of the selected companies.

Originality/Value: This paper provides some key insights to health and efficiency of the selected companies. The working capital ratios are indicative of good working capital management, leading to identifying issue in financial management and eventually improving the performance of the tyre industry.
\end{abstract}

\section{Introduction}

Working capital can be understood as a measure of both a company's efficiency and its short term economic health. For a layman, it simply means the distinction between the current assets and current liabilities. It is the firm's holdings of current, or short-term, assets (such as cash). Working capital is generally separated in two types, viz. gross working capital and net working capital. Gross Working Capital (GWC) is nothing but the total current or circulating assets. Net working capital, Net Working capital NWC (current assets minus current liabilities), provides an accurate assessment of the liquidity position of firm.

The main objective of working capital management is to maintain an optimal balance between each of the working capital components (Nazir \& Afza, 2009). Business success heavily depends on the financial executives' ability to effectively manage receivables, inventory, and payables (Filbeck \& Krueger, 2005). Firms can reduce their financing costs and/or increase the

Copyright ( 2021, Journal of Advanced Research in Economics and Administrative Sciences (JAREAS), Under a 
funds available for expansion projects by minimizing the amount of investment tied up in current assets. A popular measure of WCM is the cash conversion cycle, i.e. the time lag between the expenditure for the purchases of raw materials and the collection of sales of finished goods (Deloof, 2003). The longer this time lag, the larger the investment in working capital. A longer cash conversion cycle might increase profitability because it leads to higher sales.

India ranks as the largest manufacturer of motorcycles and second largest in manufacturing of scooters in the world. The tyre industry in India has long been recognized as a core manufacturing sector with the potential to drive national economic growth and foster the development of technological capabilities through its powerful backward and forward linkages, and the localization of high value added manufacturing processes within domestic economies (Rapheal, 2013). According to Mohanakumar \& Tharian (2001), the pace of growth of Indian tyre manufacturing industry has been unprecedented since 1970s. The number of tyre manufactures has multiplied since then, create competition and also issues of financial performance. Based on this backdrop, the aim of this study is to evaluate the financial performance of Indian tyre industry in view of some financial ratios.

\section{Literature Review}

Corporate finance literature has traditionally focused on the study of long-term financial decisions such as the structure of capital, investments, dividends and firm valuations. However, Smith (1980) suggests that working capital management is important because of its effects on a firm's profitability and risk, and consequently its value. Following this line of argument, some more recent studies have focused on how reduction of the measures of working capital improves a firm's profitability (Jose et al., 1996; Shin \& Soenen, 1998; Deloof, 2003; Padachi, 2006; Garcia-Teruel \& Martinez-Solano, 2007; Raheman \& Nasr, 2007, Almaqtari et al., 2019).

The Indian Tyre industry like all other labour intensive industries, has come a long way traversing path treaded with turbulent macro and micro environmental factors ranging from changing Governments and their policies, technological complexities, constant raw materials cost fluctuations-having direct impact on operating results, management styles and priorities and resultant unsettled human resource practices (Mathur \& Manju, 2013). Some research studies have highlighted several aspects of this industry in India. Abbasali Pouraghajan (2013) analysed the effects of working capital management and capital structure on profitability and return of assets. In this study, time span was 2006 to 2010 and data were collected in financial statements. The major suggestion is components of working capital management particularly cash management, securities traded in the stock market, inventory and accounts receivable independently. In India, Rapheal (2013) evaluated the performance of Indian tyre industry in terms of various financial indicators, trend of sales, trend of production, and trend of export. The study concluded that the tyre industry has been passing trough tumultuous stage characterized by debt burden, low effective utilisation of assets, and above all and huge liquidity crunch. For the success of the industry, the researcher suggested improving labour productivity and effectiveness, flexibility of labour and capital efficiency of the labour.

Copyright (C) 2021, Journal of Advanced Research in Economics and Administrative Sciences (JAREAS), Under a Creative Commons Attribution 4.0 International License 
In 2016, Tarannum identified considerable growth in Ceat Akkhan Ltd. Though it started its operations in 2012, the company within a short span of years made potential growth. According to Tarannum (2016), the quality of product is the main advantage of CEAT tyres. Moreover, Pinku Paul (2018) studied the effect of working capital management on profitability of some steel Industry companies. The study period of 17 years should be considered. The major finding of this study indicates that the impact of working capital management on profitability of the firm of Indian steel industry has been significant.

\section{Methodology and Procedures}

\section{Hypotheses}

The researcher formulated four null hypotheses as it follow:

$\mathrm{H}_{0}=$ There is no significant relationship between QR and NPM.

$\mathrm{H}_{0}=$ There is no significant relationship between CR and NPM.

$\mathrm{H}_{0}=$ There is no significant relationship between ITR and NPM.

$\mathrm{H}_{0}=$ There is no significant relationship between WCTR and NPM.

\section{Data Sources}

The study covers the different aspects of working capital management and establishes a relation among two variables which are working capital management and profitability of tyre industry. The period of the study covers 8 years; that is, 2011-12 to 2018-19. The data was mainly collected form related secondary sources.

\section{Sample Frame}

The sample units of this study were selected from the companies in the tyre industry as per market capitalisation as on $24^{\text {th }}$ December 2019. Higher market capitalisation companies were selected for the study. The sample includes three companies: Balkrishna Industry, Apollo, and Ceat.

\section{Empirical Model}

For this study, an empirical model was developed to study the significance or relation and impact of the working capital management ratios and profitability of selected tyre firms in India by using the panel data and multiple regression models:

\section{Results and Discussion}

$$
Y_{i t}=\beta_{0}+\beta_{1} A_{i t}+\beta_{2} A_{i t}+\beta_{3} A_{i t}+\varepsilon_{i t}
$$

\footnotetext{
Calculation of Ratio: $\mathbf{N P M R}=$ Net profit after interest and tax $/$ Net sales $\times 100$

$\mathbf{C R}=$ Current Assets / Current Liabilities

$\mathbf{Q R}=$ Current Assets - Inventories $/$ Current Liabilities

$\mathbf{I T R}=$ Net Sales $/$ Inventories

WCTR = Net Sales/ Working capital
}

Copyright (C) 2021, Journal of Advanced Research in Economics and Administrative Sciences (JAREAS), Under a Creative Commons Attribution 4.0 International License 
Table 1: NPMR and CR, QR, ITR, WCTR of Selected Companies

\begin{tabular}{|l|l|l|l|l|l|l|}
\hline $\begin{array}{l}\text { Balkrishna } \\
\text { Industry }\end{array}$ & YEAR & $\begin{array}{l}\text { NPMR in } \\
(\%)\end{array}$ & $\begin{array}{l}\text { CR in } \\
\text { (Times) }\end{array}$ & $\begin{array}{l}\text { QR in } \\
\text { (Times) }\end{array}$ & $\begin{array}{l}\text { ITR in } \\
\text { (Times) }\end{array}$ & $\begin{array}{l}\text { WCTR in } \\
(\text { Times }\end{array}$ \\
\hline & $2011-12$ & 9.52 & 1.5 & 1.03 & 5.86 & 5.45 \\
\hline & $2012-13$ & 11.15 & 1.67 & 1.17 & 7.38 & 5.45 \\
\hline & $2013-14$ & 13.65 & 1.28 & 0.81 & 6.76 & 11.38 \\
\hline & $2014-15$ & 12.93 & 1.38 & 1.12 & 9.64 & 6.61 \\
\hline & $2015-16$ & 17.51 & 1.06 & 0.87 & 11.32 & 37.35 \\
\hline & $2016-17$ & 19.19 & 1.07 & 0.78 & 8.11 & 34.15 \\
\hline & $2017-18$ & 16.62 & 1.42 & 0.99 & 7.48 & 7.41 \\
\hline & $2018-19$ & 14.91 & 1.76 & 1.25 & 7.36 & 4.81 \\
\hline & Average & 14.435 & 1.3925 & 1.0025 & 7.98875 & 14.07625 \\
\hline & & & & & & \\
\hline & $2011-12$ & 2.22 & 0.86 & 0.34 & 7.34 & -26.19 \\
\hline & $2012-13$ & 3.67 & 0.97 & 0.34 & 7.59 & -149.73 \\
\hline & $2013-14$ & 5.08 & 0.9 & 0.33 & 6.79 & -38.37 \\
\hline & $2014-15$ & 7.21 & 0.97 & 0.4 & 7.59 & -125.83 \\
\hline & $2015-16$ & 11.44 & 1.16 & 0.67 & 8.59 & 25.57 \\
\hline & $2016-17$ & 8.89 & 1.11 & 0.51 & 5.71 & 28.56 \\
\hline & $2017-18$ & 6.04 & 1.59 & 1.03 & 5.98 & 5.7 \\
\hline & $2018-19$ & 4.79 & 1.35 & 0.52 & 6.02 & 14.34 \\
\hline & Average & 6.1675 & 1.11375 & 0.5175 & 6.95125 & -33.2438 \\
\hline & & & & & & \\
\hline & $2011-12$ & 6.16 & 0.81 & 0.47 & 7.72 & -13.31 \\
\hline & $2012-13$ & 2.17 & 0.76 & 0.47 & 9.19 & -11.24 \\
\hline & $2013-14$ & 4.73 & 0.9 & 0.51 & 7.46 & -27.37 \\
\hline & $2014-15$ & 5.34 & 1.17 & 0.75 & 8.71 & 21.42 \\
\hline & $2015-16$ & 8.23 & 1.21 & 0.69 & 8.87 & 21.48 \\
\hline & $2016-17$ & 6.36 & 1.36 & 0.67 & 6.17 & 11.64 \\
\hline & $2017-18$ & 4.52 & 1.01 & 0.57 & 8.16 & 525.12 \\
\hline & $2018-19$ & 4.22 & 0.95 & 0.49 & 7.08 & -71.89 \\
\hline & Average & 5.21625 & 1.02125 & 0.5775 & 7.92 & 56.98125 \\
\hline
\end{tabular}

Source: Annual Reports of Selected Companies

The table above presents the net profit margin ratio as dependent variable, whereas current ratio, quick ratio, inventory turnover ratio, working capital turnover ratio as independent variable for the study period of 2011-12 to 2018-19 respectively. Net profit margin ratio of Balkrishana industry was increasing up to the year 2016-17. Further it was declined in the year 2017-18 and 2018-19. The average ratio of Balkrishan industry was $14.43 \%$ for the study period. Average Current ratio and quick ratio of Balkrishna industry was 1.39:1 and 1:1 in which former not satisfied with standard ratio which is $2: 1$ and later satisfied with standard which is $1: 1$. Inventory 
turnover ratio and working capital turnover ratio indicated sound working capital management in Balkrishan industry during the study period.

The results of Apollo Tyre indicated average net profit margin ratio 6.16\% with fluctuating trend in the study period. Current ratio and quick ratio of Apollo were 1.11:1 and 0.52:1 as average during the study period. However, both ratios were not satisfactory since they do not meet the standard which is specified above. In Apollo Tyre, the inventory turnover ratio was 6.95 time and working capital turnover ratio was -33.24 time. This clearly reflects negative working capital management during the study period.

Out of the selected three companies Ceat indicated the lowest average net profit margin ratio as $5.21 \%$ and current ratio and quick ratio indentified as 1.02:1 and 0.57:1 during the study period. Ceat had the second highest inventory turnover ratio which was 7.92 time. Sound working capital has been identified in Ceat due to 56.98 times during the study period.

\begin{tabular}{|l|l|l|l|l|l|l|}
\hline ANOVA Test \\
\hline Particulars & \multicolumn{2}{|l}{ Balkrishan } & Apollo & Ceat & \\
\hline & F & Signi. F & F & Signi. F & F & Signi. F \\
\hline F- test & 1.02986 & 0.5109 & 0.4919 & 0.7481 & 0.6098 & 0.6851 \\
\hline
\end{tabular}

Based on Anova test for all the selected companies, the results show no statistical evidence. Hence, there is no relation or impact of selected ratios on net profit margin.

\section{Regression Analysis}

\begin{tabular}{|l|l|l|l|}
\multicolumn{4}{|c}{ NPMR $_{\text {it }}=\alpha+\beta_{1} \mathrm{CR}_{\text {it }}+\mathrm{QRA}_{\text {it }}+\mathrm{ITRA}_{\text {it }}+\mathrm{WCTRA}_{\text {it }}+\varepsilon_{\text {it }}$} \\
\hline & Balkrishana & Apollo & Ceat \\
\hline Multiple R & 0.760669813 & 0.629360061 & 0.669678 \\
\hline R Square & 0.578618565 & 0.396094086 & 0.448468 \\
\hline Adjusted R Square & 0.016776651 & -0.409113799 & -0.28691 \\
\hline Standard Error & 3.243426525 & 3.510363207 & 2.024331 \\
\hline Observations & 8 & 8 & 8 \\
\hline
\end{tabular}

The Anova table and regression tables show that the model is not statistically significant for impact on profitability or prediction of net profit for selected ratios. In relation with $\mathrm{r}^{2}$ (coefficient of determination) with Balkrishana, Apollo, Ceat indicated 57.86\%, 39.60\%, $44.84 \%$ of net profit was explained by this model. The results of regressions suggest that managers can increase corporate profitability by reducing the number of days accounts receivable and inventories.

An alternative explanation for the negative relation between accounts receivable and profitability could be that customers want more time to assess the quality of products they buy from firms with declining profitability. These results suggest that managers can create value for their 
shareholders by reducing the number of days accounts receivable and inventories to a reasonable minimum. The negative relation between accounts payable and profitability is consistent with the view that less profitable firms wait longer to pay their bills. A firm may adopt an aggressive working capital management policy with a low level of current assets as a percentage of total assets, or it may also be used for the financing decisions of the firm in the form of high level of current liabilities as a percentage of total liabilities (Nazir \& Afza, 2009).

\section{Conclusion and Suggestion}

The study aimed at measuring the impact of working capital management on the profitability of some tyre manufacturers in India. The results of the study indicate that the highest net profit margin ratio of Balkrishana LTD in consideration with the year 2016-17 as 19.19\% during the study period. Regarding the performance of selected companies in relation to working capital management, Ceat shows a good performance, whereas Apollo shows negative performance because the current liabilities of the company are more than the current assets. Regression analysis helps to identified effect of working capital management on profitability for selected companies in $57.86 \%, 39.60 \%, 44.84 \%$ to the Balkrishana, Apollo, Ceat respectively.

\section{Conflict of Interest}

The author of the article declares no conflict of interest.

\section{Funding}

This research study was not funded by any institution. The author conducted the study on his own expenses.

\section{References}

Abbasali Pouraghajan, E. A. (2013). Investigation the effects of working capital managemet and capital structure on profitability and return on assets (case study: a section from the automotive companies in Iraq). Journal of Basic and applied scientific research , 847 854.

Abdulkareem, A. M. (2020). Financial Performance of Indian Pharmaceutical Companies: Analysis of Leverage and Cost of Capital. Journal of Advanced Research in Economics and Administrative Sciences, 1(1), 13-22. https://doi.org/10.47631/jareas.v1i1.15

Almaqtari, F. A., Al-Homaidi, E. A., Tabash, M. I., \& Farhan, N. H. (2019). The determinants of profitability of Indian commercial banks: A panel data approach. International Journal of Finance \& Economics, 24(1), 168-185.

Deloof, M. (2003). Does working capital management affect profitability of Belgian firms?. Journal of business finance \& Accounting, 30(3-4), 573-588.

Filbeck G and Krueger T (2005), "Industry Related Differences in Working Capital Management", Mid-American Journal of Business, Vol. 20, No. 2, pp. 11-18.

Garc1'a-Teruel, P. J., and P. Martı'nez-Solano, 2007b, Short-term debt in Spanish SMEs,

Copyright (C) 2021, Journal of Advanced Research in Economics and Administrative Sciences (JAREAS), Under a Creative Commons Attribution 4.0 International License 
Internacional Small Business Journal 25, 579-602.

Jose, M. L., C. Lancaster, and J. L. Stevens, 1996, Corporate return and cash conversion cycle, Journal of Economics and Finance 20, 33-46.

Mathur, M., \& Manju, N. (2013). Industrial Relations-A Study of Perception of Managers of Tyre Industry. IRJBM, 74, (81), 74-83.

Mohanakumar, S., \& Tharian George, K. (2001). Impact of Economic Reforms on Tyre Industry. Economic and political weekly, 1044-1050.

Nazir, M. S., \& Afza, T. (2009). Impact of Aggressive Working Capital Management Policy on Firms' Profitability. IUP Journal of Applied Finance, 15(8).

Padachi, K., 2006, Trends in working capital management and its impact on firms' performance: an analysis of Mauritian small manufacturing firms, International Review of Business Research Papers 2, 45-58.

Pinku Paul, P. M. (2018). Analysis of the effect of working capital management on profitability of the firm: evidence from indian steel industry. Asia - Pacific Journal of Management Research and Innovation (14(1-2)), 32-38.

Rajiv, B. (2017, March 20). Recent Development and growth trends in Automobile and tyre industry in India - implications for the NR Sector. Proceedings of International Rubber Conference 2017 , pp. 67 - 90.

Rapheal, N. (2013). An overview of the finanical peformance of indian tyre industry comparison among leading tyre companies. Innovative Journal of business and management, 128 - 134 .

Raheman, A., and M. Nasr, 2007, Working capital management and profitability - case of Pakistani firms, International Review of Business Research Papers 3, 275-296.

Shin, H. H., and L. Soenen, 1998, Efficiency of working capital and corporate profitability, Financial Practice and Education 8, 37-45.

Sunil.M, S. K. (2014). A study on financial peformance: a comparative analysis of JK tyres industries Ltd and selected tyre companies in India . Zenith International Journal of Business Economics and Management Research, 73 - 80.

Tarannum, I. (2016). Study on consumer behaviour with special refernce to preference of brands in tyre industry - with CEAT tyre. Brac Univeristy Mohakhali, Bangladesh . Bangladesh : online sources . 